\title{
PRODUCTION OF PLANTLETS FROM CROWN EXPLANT OF PINEAPPLE VARIETY 'QUEEN'
}

\author{
ALMA P. ROSILLO \\ Office of the Director of Research and Development \\ Leyte State University, Visca, Baybay, Leyte 6521-A, Philippines \\ and

\section{MARILYN M. BELARMINO} \\ Department of Horticulture, College of Agriculture, Leyte State University \\ Visca, Baybay, Leyte 6521-A, Philippines
}

\section{ABSTRACT}

To maximize the utilization of crown and to increase the production of plantlets, the crown was divided into four (for microsectioning technique) or eight (for in vitro micropropagation technique) sections and used as explants. Results showed the efficiency of the in vitro culture technique compared to the microsectioning method in producing axillary shoots from the crown explant. Using the in vitro culture technique, 1/8 crown explant produced an average of 1.4 and 1.6 axillary shoots (or 11.2 and 12.8 shoots per whole crown) after 14 to 25 days of initial culture in MS medium containing combinations of $0.2 \mathrm{mg} / \mathrm{L} / \mathrm{AA}$ and $0.5 \mathrm{mg} / \mathrm{L} B A$ or, $2.0 \mathrm{mg} / \mathrm{L} \mathrm{NAA}$ and $2.0 \mathrm{mg} / \mathrm{L} \mathrm{BA}$, respectively. These shoots proliferated and produced an average of 47.1 or 55.1 micro shoots after four months of culture in MS medium added with $0.5 \mathrm{mg} / /$ or $1.0 \mathrm{mg} / \mathrm{BA}$. On the contrary, one quarter crown explant of the microsectioning technique produced an average of 0.2 shoot in soil or, 0.8 shoot from one whole crown. The crown-derived shoots rooted easily in $1 / 2$ MS medium, established well in soil, reached maturity and produced fruits.

KEYWORDS: Axillary buds. Adventitious shoots. Micropropagation. Shoot proliferation. 


\section{INTRODUCTION}

Pineapple production contributes substantially to the export earnings of the Philippines. It ranks second place in domestic agricultural production of fruits and nuts - behind the cultivation of banana. About $30 \%$ of pineapple production in the Philippines is exported (Mouse Movements, 2005). The Philippines, Costa Rica, and Côte d"Ivoire supply $60 \%$ of fresh fruits in the European market.

The demand for fresh fruit pineapples in the temperate market is steadily increasing (D'eeckenbrugge and Leal, 2001; Global Market/ www.tradenets!k/pine/global.htm). To cope with the demand, more pineapple should be planted. Increasing the hectarge of pineapple plantation means greater need for planting materials. Sadly, however, the traditional planting materials such as crown ("tops") and slips (side shoots arising from older leaf axils) would be insufficient (Gangopadhyay et al., 2005). A viable alternative is micropropagation technique that permits the production of uniform and disease-free plantlets at a high propagation rate in a short period of time and small space. This technique has been used to support breeding programs allowing rapid multiplication of selected clones, besides conservation and exchange of germplasm (Mello, etal., 2005).

Recently, the 'Queen' variety of pineapple has gained attention in the international and domestic markets because of its sweetness, low fiber content, and crispiness. It is now being exported as fresh fruit to Hongkong, China, and Japan (Amo, 2005). Most importantly, 'Queen' is a potential source of disease-resistance genes for varietal improvement. The 'Queen'variety is robust, showing more tolerance to stress, insect pests and diseases than 'Smooth Cayenne' (Rangan, 1984). 
Many authors have reported the micropropagation of pineapple using different varieties (Dewald etal, 1988; Cabral etal, 1985; Wakasa et al, 1978; De Almeida et al, 1997; Zepada and Sagawa, 1981; Kiss et al, 1995). Most of these reports, however, were on 'Smooth Cayene' variety (Fitchet-Purnell, 1993) and very limited reports on the 'Queen' variety.

The present paper discusses the potential of crown as explant for clonal propagation of pineapple variety 'Queen' and, the effects of plant growth regulators and vitamins on the initiation and proliferation of axillary shoots, and rooting of plantlets. Results of this study are expected to provide information that can be applied for the propagation, conservation and genetic. manipulation of 'Queen' and other elite pineapple varieties.

\section{MATERIALS AND METHOD}

\section{Preparation of Crown Explants}

Crowns detached from ripe fruit of pineapple variety 'Queen' were collected from the field. The butt of each crown was soaked in $0.1 \%$ fungicide solution (e.g. antracol) for 15 mins. Curing, which is the process of drying the stem before planting, was done by air-drying the crowns upside-down inside the screenhouse for 2-6 weeks prior to use. The crowns were prepared for microsectioning and in vitro micropropagation experiments.

Microsectioning of crown was done by trimming the crown leaves leaving 1.0 to $2.5 \mathrm{~cm}$ leaf bases attached to the crown stalk. The trimmed crown stalks were sliced longitudinally into quarter sections. One quarter section served as one explant. 
The crown explants used for micropropagation technique were prepared by defoliating the cured crown. These were surface sterilized using $0.1 \%$ of fungicide solution (e.g. benlate) for $15 \mathrm{~min}$ and then, rinsed 3 times with sterile distilled water. Defoliated crowns of about 20 to $36 \mathrm{~g}$ (f. w.) were disinfected with $15.0 \%$ of commercial bleaching solution e.g. Zonrox (a.i. $5.25 \%$ sodium hyphochlorite) added with 2 to 3 drops of Tween 20 , for 35 min. The decontaminated crown explants were aseptically cut into 8 longitudinal equal parts, each measuring $1.0 \mathrm{~cm}$ in length. One eight crown section served as one explant.

\section{Initiation of Axillary Shoots from Crown Explants}

a. Microsectioning vs. in vitro micropropagation technique

The production of axillary shoots using microsectioning and in vitro micropropagation techniques were compared. Thirty microsectioned explants (quarter section) were planted into sterile soil mixture composed of compost, garden and alluvial soil at 1:1:1 (v/v) ratio and grown in the screenhouse. These were sprayed with fungicide (1.0 tbsp anthracol/16L of water) and fertilizer ( $1.0 \mathrm{tbsp}$ Urea/ $4 \mathrm{~L}$ of water) solutions once every other week. For the micropropagation technique, $1 / 8$ crown explants were cultured in MS medium containing $30.0 \%$ refined white table sugar, $0.1 \mathrm{mg} / \mathrm{indole}$ acetic acid (IAA), $0.5 \mathrm{mg} / \mathrm{L}$ benzyladenine (BA) and solidified with $0.6 \%$ agar-agar (Pronadisa, Hispanlab, S.A. Madrid) at pH 5.8. Thirty crown explants were incubated in the dark at $251^{\circ} \mathrm{C}$ until bud emergence followed by exposure to $24 \mathrm{hr}$ light from two $40-\mathrm{W}$ fluorescent tubes. The agarsolidified MS basal medium and incubation condition mentioned above were used throughout this study. 


\section{b. Effects of plant growth regulators and vitamins}

The effects of plant growth regulators (PGRs) and vitamins on the initiation of shoots from excised crown explants were evaluated using the in vitro micropropagation technique. The PGRs; naphthalene acetic acid (NAA; $0.2,0.5$ and $2.0 \mathrm{mg} / \mathrm{L}), \mathrm{IAA}(0.2 \mathrm{mg} / \mathrm{L})$, indole butyric acid (IBA; $2.0 \mathrm{mg} / \mathrm{L}), \mathrm{BA}$ $(0.5$ and $2.0 \mathrm{mg} / \mathrm{L})$, kinetin $(2.0 \mathrm{mg} / \mathrm{L})$ and, vitamins; myo-inositol (100 $\mathrm{mg} / \mathrm{L})$, thiamine- $\mathrm{HCl}(30 \mathrm{mg} / \mathrm{L})$, pryridoxine $-\mathrm{HCl}(10 \mathrm{mg} / \mathrm{L})$, glycine $(2.0$ $\mathrm{mg} / \mathrm{L}$ ) and coconut water (15\%) were added into the agar-solidified $\mathrm{MS}$ basal medium (initiation medium) at pH 5.8 that served as treatments. These treatments were chosen based from their favorable effects during preliminary experiments (data not shown). Each treatment medium was dispensed at $10 \mathrm{ml}$ per culture bottle prior to autoclaving at $15 \mathrm{psi}$ for $20 \mathrm{~min}$. The autoclaved medium was allowed to cool before inoculating the crown explants.

\section{Proliferation of Adventitious Shoots and Rooting}

To further increase the number of shoots, the crown-derived shoots were transferred individually to the proliferation medium composed of agarsolidified MS medium supplemented with BA $(0.5 \mathrm{mg} / \mathrm{l}$ and $1.0 \mathrm{mg} / \mathrm{L})$ or, combinations of $B A(0.5 \mathrm{mg} / \mathrm{lor} 1.0 \mathrm{mg} / \mathrm{L})$ and adenine sulfate $(10.0 \mathrm{mg} / \mathrm{L})$ and incubated for one month under $24 \mathrm{~h}$ light at $251^{\circ} \mathrm{C}$. The clumps of adventitious shoots produced from the base of each shoot explant were again separated and individually transferred to agar-solidified $1 / 2 \mathrm{MS}$ medium with or without $0.5 \mathrm{mg} / \mathrm{L}$ IBA to induce rooting. Well-rooted plantlets were acclimatized for two weeks at ambient room temperature and then, potted in soil mixture that was used for the microsectioned crowns. The plantlets were allowed to grow inside the screenhouse for two months and then, transplanted in the field. 


\section{Research Design and Statistical Analysis}

All experiments were laid out in a Completely Randomized Design with a minimum of 10 samples per treatment and replicated three times. The treatment means were compared using Duncan's Multiple Range Test and Least Significance Difference.

\section{RESULTS AND DISCUSSION}

\section{Initiation of Axillary Shoots from Crown Explants}

\section{a. Microsectioning versus micropropagation technique}

Faster emergence of axillary shoots (after 21 days) was observed from the $1 / 8$ crown explants cultured under the in vitro micropropagation technique (Figure 1A) compared to the quarter crown explants (after 37 days) grown in soil (Figure 1B) under the conventional microsectioning technique. Likewise, $20 \%$ of the $1 / 8$ crown explants produced axillary shoots in MS medium whereas, only $15.5 \%$ of the quarter crown explants did in soil. Since one $1 / 8$ crown explant produced an average of 0.5 axillary shoot under in vitro culture, a total of 4.0 shoots were obtained per one whole crown. On the contrary, a quarter crown explant produced an average of 0.2 shoot in soil hence, only 0.8 axillary shoot was obtained from one whole crown (Figure 2).

The beneficial effect of $i n$ vitro micropropagation technique on axillary shoot production from crown explants can be attributed to its aseptic condition, enriched medium, and controlled environmental condition. On the other hand, the quarter crown sections planted in soil are prone to desiccation or rotting resulting in high mortality. Considering the advantages of $1 / 8$ crown explant and in vitro technique, these were used in the succeeding experiments: 

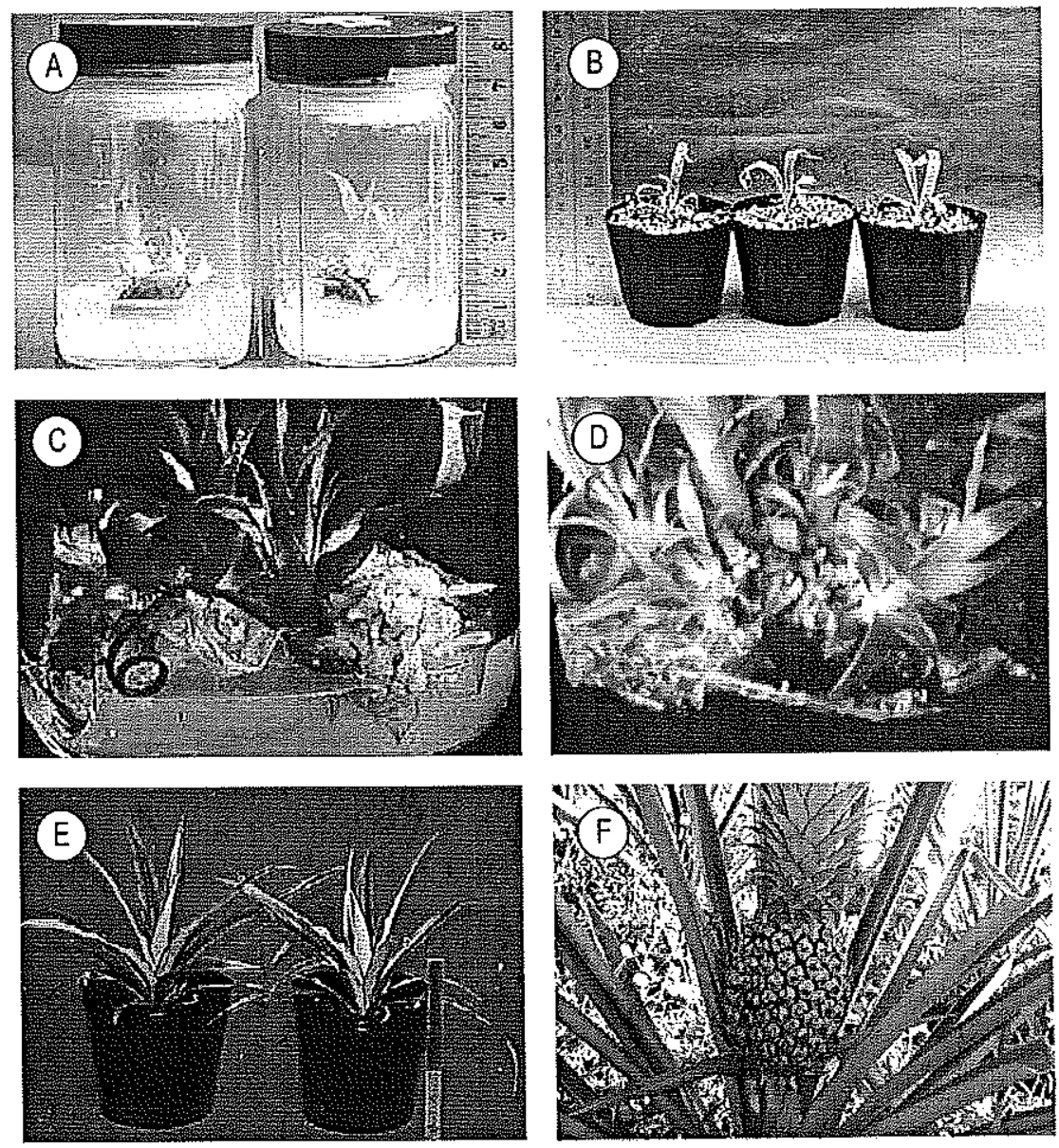

Figure 1. Plant production from crown explants of pineapple variety 'Queen'. Axillary shoots derived from in vitro cultured $1 / 8$ crown explant $(A)$ and quarter crown explant $(B)$, proliferation of adventitious shoot buds $(C)$, cluster of micro shoots (D), crown-derived plants potted in soil and, (F) mature plant bearing fruit. 


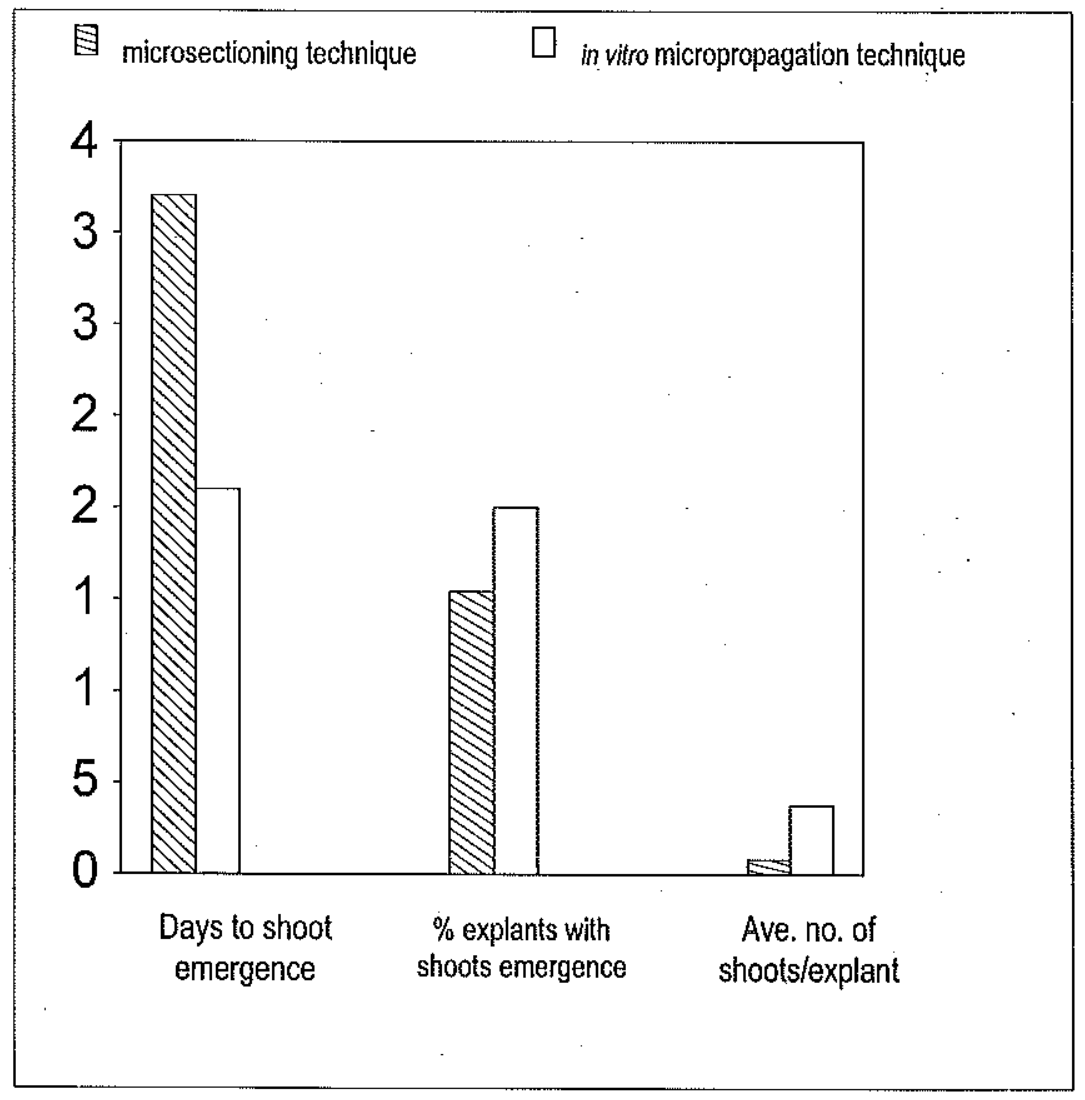

Figure 2. Response of quarter crown explants grown in soil using microsectioning technique and $1 / 8$ crown explant cultured in MS medium using in vitro micropropgation technique. 


\section{b. Effects of plant growth regulators and vitamins}

Shoots were obtained from dormant axillary buds of the crown explant cultured in MS medium supplemented with PGRs and vitamins (Table 1). A noticeably high percentage $(55.8 \%)$ of axillary shoot formation was observed from the crown explants cultured in MS medium supplemented with $2.0 \mathrm{mg} / \mathrm{L}$ $\mathrm{NAA}$ and $2.0 \mathrm{mg} / \mathrm{L} \mathrm{BA}\left(\mathrm{T}_{3}\right)$ that was recommended by Wakasa et al. (1978). The effective combination of NAA and BA in inducing shoot formation has been reported in tissue culture studies using 'Smoot Cayenne' variety (Khatun et al., 1997). Generally, the PGR and vitamin supplements of the treatment media induced faster emergence of axillary shoots from the crown explant (except $\mathrm{T}_{3}$ ) compared to the control medium $\left(\mathrm{T}_{0}\right)$. However, the differences were not statistically significant.

Table 1. Initiation of auxiliary shoots from crown explants of pineapple var. "Queen" in agar-solidified MS medium supplemented with plant growth regulators and vitamins

\begin{tabular}{|c|c|c|c|c|}
\hline Treatment' (mg/L) & $\begin{array}{c}\% \text { explants } \\
\text { with axillary } \\
\text { shoots }\end{array}$ & $\begin{array}{l}\text { Ave. no of days } \\
\text { to axillary shoot } \\
\text { emergence }\end{array}$ & $\begin{array}{l}\text { Ave. no of } \\
\text { axillary shoots } \\
\text { explant }\end{array}$ & $\begin{array}{c}\text { Estimated no. } \\
\text { of axillary } \\
\text { shoots per } \\
\text { whole crown }\end{array}$ \\
\hline$T_{0}-0$ & 20.0 & 21.0 & $0.5^{\text {ns }}$ & 4.0 \\
\hline$T_{1}-0.2 \mathrm{IAA}+0.5 \mathrm{BA}$ & 53.3 & 19.0 & $1.6^{*}$ & 12.8 \\
\hline $\mathrm{T}_{2}-0.5 \mathrm{NAA}+1.0 \mathrm{BA}$ & 40.5 & 19.1 & $1.1^{\text {ns }}$ & 8.8 \\
\hline$. \mathrm{T}_{3}-2.0 \mathrm{NAA}+2.0 \mathrm{BA} 2$ & 55.8 & 18.6 & $1.4^{*}$ & 11.2 \\
\hline$T_{4}-3 / 4 M S+0.21 A A+0.5 B A$ & 52.4 & 17.2 & $0.6^{\text {ns }}$ & 4.8 \\
\hline $\begin{array}{l}T_{5}+0.2 N A A+0.5 B A \\
T_{6}-M S+100 M+30 T+10\end{array}$ & 23.8 & 14.1 & $0.6^{\text {ns }}$ & 4.8 \\
\hline $\begin{array}{l}\mathrm{P}+2 \mathrm{G}+2.0 \mathrm{NAA}+2.0 \mathrm{BA} \\
\mathrm{T}_{7}-\mathrm{MS}+2.0 \mathrm{NAA}+2.0 \mathrm{IBA}\end{array}$ & 41.1 & 19.2 & $0.7^{\mathrm{ns}}$ & 5.6 \\
\hline+2.0 kinetin $+15 \% \mathrm{CW}$ & 48.3 & 25.2 & $1.0^{\text {ns }}$ & 8.0 \\
\hline C.V. $(\%)$ & 87.09 & 18.76 & 35.38 & \\
\hline
\end{tabular}

Mean separated by LSD at $5 \%$ level. ${ }^{\text {ns }}$ not significant; * significant

'T-thiamine, M-myo-inositol, P-pyridoxine, G-glycine, CW-coconut water

${ }^{2}$ The estimated number of shoots produced per whole crown was computed by multiplying the average number of axillary shoots/explant with 8 . 
After two months of culture, the significant effects of the treatment media over that of the control medium were shown by differences in the average number of axillary shoots that were produced from one crown explant (Table 1). Treatments $T_{1}(0.2 \mathrm{mg} / \mathrm{L} I A A$ and $0.5 \mathrm{mg} / \mathrm{L} \mathrm{BA}), T_{3}(2.0 \mathrm{mg} / \mathrm{L} \mathrm{NAA}$ and $2.0 \mathrm{mg} / \mathrm{L} \mathrm{BA})$ and $\mathrm{T}_{4}(3 / 4$ strength $\mathrm{MS}$ medium with $0.2 \mathrm{mg} / \mathrm{LIAA}$ and $0.5 \mathrm{mg} / \mathrm{L}$ BA) significantly induced an average production of 1.4 to 1.6 axillary shoots per $1 / 8$ crown explant (or 11.2 to 12.8 shoots per one whole crown) compared to 0.5 to 1.0 shoot per explant (or 4.0 to 8.0 shoots per one whole crown) of the control medium $\left(\mathrm{T}_{0}\right)$. The rates of shoot production from other treatment media $\left(T_{2}, T_{5}, T_{6}\right.$ and $\left.T_{7}\right)$ were comparable to the control medium $\left(T_{0}\right)$ (Table 1).

Although the addition of vitamins and reduction of MS salts were found to enhance the growth of some Bromeliads (George and Sherington, 1984), this was not observed in pineapple. The number of axillary shoots formed in $\mathrm{T}_{1}$ and $\mathrm{T}_{4}$ media did not vary (Table 1). Thus, the reduction of MS formulation from full to $3 / 4$ strength and the addition of myo-inositol and thiamine in culture medium $\left(T_{4}\right)$ were not critical for axillary shoot formation in 'Queen' pineapple. On the contrary, it is the appropriate combination of PGRS, that is, auxin and cytokinin in the initiation medium that significantly influenced the production of axillary shoots in pineapple.

\section{Proliferation of Micro Shoots}

The axillary shoots obtained from $1 / 8$ crown sections were transferred to the proliferation medium composed of agar-solidified MS basal medium that was added with either $0.5 \mathrm{mg} / \mathrm{LBA}, 1.0 \mathrm{mg} / \mathrm{L} \mathrm{BA}$ or, $0.5 \mathrm{mg} / \mathrm{L} \mathrm{BA}$ and $10 \mathrm{mg} / \mathrm{L}$ adenine sulfate to induce multiple shoot formation. The proliferation of adventitious shoots was marked by the swelling of shoot base, which was followed by the protrusion of globular structures after 2 to 4 weeks of culture (Figure $1 \mathrm{C}$ ), leading to the formation of shoot buds. About 56.6 to $71.7 \%$ of the shoot explants cultured in proliferation medium containing 0.5 or 1.0 $\mathrm{mg} / \mathrm{L} \mathrm{BA}$ respectively, produced an average of 47.1 and 55.1 micro shoots per shoot explant. These were significantly higher than the medium added 
with a combination of $0.5 \mathrm{mg} / \mathrm{L} \mathrm{BA}$ and $10 \mathrm{mg} / \mathrm{L}$ adenine sulfate or, the medium lacking BA (control) (Figure 3). The rate of micro shoot production in this experiment was higher than those reported in 'Smooth Cayenne' variety (De Almeida et al. 1997; Kiss et al. 1995; Fitchet 1990; DeWald et al. 1988) but lower than the one reported by Firoozabady and Gutterson (2004).

In this study, continued production of micro shoots was observed when the shoots buds were subcultured to the same medium. After 2 months, the micro shoots showed a tendency to coalesce and make an inseparable clump. Similar phenomenon has been reported in many micropropagation programmes due to the effect of high concentration of BA (Gangopadhyay et al., 2005). To speed up the development of micro shoots, these were transferred in $1 / 2$ MS medium. During this culture phase, the initial shoot used as explant senesced while profuse micro shoot production continued (Figure 1D).

\section{Rooting of Crown-derived Shoots}

Seventy five percent of crown-derived plantlets produced 3-4 roots with root hairs in the agar-solidified $1 / 2$ MS medium whereas, $64 \%$ formed one to two roots without root hairs in $1 / 2 \mathrm{MS}$ medium containing $0.5 \mathrm{mg} / \mathrm{L} \mathrm{IBA}$. It appears that root primordia were already formed at the base of the shoots during the shoot proliferation stage hence, the reduced form of MS medium was sufficient to induce its differentiation into new roots. The rooted plantlets survived in soil mixture (Figure $1 \mathrm{E}$ ) whereas, the unrooted shoots were not able to initiate roots in the soil and eventually died 1 to 2 weeks after potting. Using the present method, it takes 3 to 4 months from initial culture of crown explant to the establishment of crown-derived plantlets in soil. About 20 crown-derived plantlets were planted in the field that reached maturity and produced fruits (Figure $1 F$ ). 


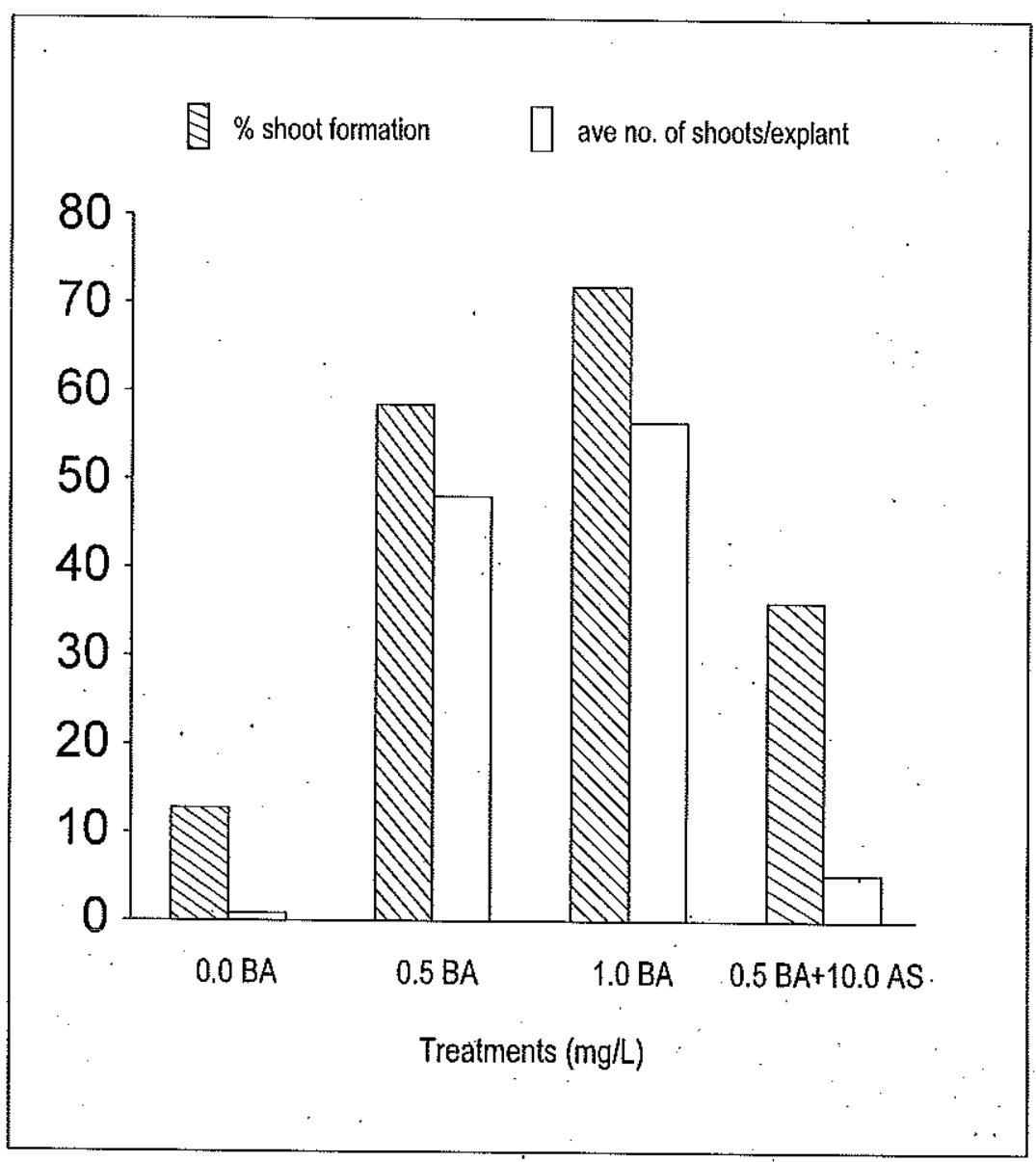

Figure 3. Response of crown-derived shoot explants in agar-solidified MS medium supplemented with benzyl adenine (BA) and adenine sulfate (AS). 


\section{CONCLUSION}

Crown sections are suitable explants for clonal propagation of pineapple variety 'Queen' using in vitro culture technique. The agar-solidified MS medium containing $30 \mathrm{~g} / \mathrm{L}$ sugar and supplemented with combinations of 0.2 $\mathrm{mg} / \mathrm{L} / \mathrm{AA}$ and $0.5 \mathrm{mg} / \mathrm{LBA}$ or, $2.0 \mathrm{mg} / \mathrm{LNAA}$ and $1.0 \mathrm{mg} / \mathrm{LBA}$ are effective for breaking axillary bud dormancy and initiating shoot formation. For the proliferation of micro shoots, the MS medium containing $0.5 \mathrm{mg} / \mathrm{lor} 1.0 \mathrm{mg} / \mathrm{L}$ BA was equally effective. An average of 47 to 55 plantlets can be produced from one shoot explant after 4 months of culture. The crown-derived plantlets established well in soil.

The in vitro culture procedure established in this study has the potential to produce thousands of plants per year for utilization in commercial pineapple plantations. The procedure can also be used to rapidly multiply limited breeding materials, to duplicate germplasm and to generate in vitro plantlets that can be used as source of vegetative explants for various studies.

\section{LITERATURE CITED}

MOUSE MOVEMENTS. 2005. Pineapple cultivation in the Philippines. http://home.arcor.de/be/bethge/ananaseng.htm

D'EECKENBRUGGE, G.C. andF.LEAL. 2001.Pineapple.

http://www.ciat.cgiar.org/ipgriffruits from americas/frutales/more $\% 20$ about

- \%20pineapple.htm

GLOBAL MARKET. Pineapple. http://www.tradenetsl.Ik/pine/global.htm

AMO, CT. June 25, 2002. Daet Pineapple: The Sweetest in the World. http://www.newsflash.org/2002/06/si/si001259.htm 
MELLO, M.R.F, S.M.DASSIS, R.L.R.MARIANO, T.R.CAMARA and M. MENEZES. 2005. Screening of bacteria and bacterization methods for growth-promotion of micropropagated pineapple plantlets.

http://www.ag.auburn.edu/argentina/pdfmanuscripts/mello

BHATIA, P. and N. ASHWATH. Development of a rapid method for micropropagation of a new pineapple (Ananas comosus (L.) Murr.) clone, 'Yeppoon Gold'. http://www.actahort.org/

CABRAL, J.R.S, G.A.P. CUNHA and E.M. RODRIGUEZ. 1985. Pineapple micropropagation. Hort.Abstr. 55(9):7342.

DE ALMEIDA, W.A.B., A.P.DE MATOS and A. DAS SOUZA. 1997. Effects of benzylaminopurine (BAP) on in vitro proliferation of pineapple (Ananas comosus(L.) Merr.). Acta Hort. 425:235-242.

DEWALD, M.G., G.A. MOORE, W.B. SHERMAN and M.H. EVANS. 1988. Production of pineapple plants in vitro. Plant Cell Reports 7:535-537.

FIROOZABADY, E. AND N. GUTTERSON. 2003. Cost-effective in vitro propagation methods for pineapple. Plant Cell Rep. 29(9). http://www.actahort;orgl

FITCHET-PURNELL, M. 1993. Maximum utilization of pineapple crowns for micropropagation. Acta Hort. 334:325-330.

GANGOPADHYAY, G., T. BANDYOPADHYAY, R. PODDAR, S. B. GANGOPADHYAY and K. K. MUKHERJEE. 2005. Encapsulation of pineapple micro shoots in alginate beads for temporary storage. Curr. Science 66(8). http://www.actahort.org/

GEORGE, E.F. and P.D. SHERINGTON. 1984. Plant propagation by tissue culture. Exegetics Limited, England. pp. 194, 284-330. 
KHATUN, M. M., D. KHANAM, M. A. HOQUE and A. QUASEM. 1997. Clonal propagation of pineapple through tissue culture. Plant Tissue Cult. $7(2): 143-148$.

KISS, E., J. KISS, G. GYULAI and L.E. HESZKY. 1995. A novel method for rapid micropropagation of pineapple. Hort Science 30(1):127-129.

WAKASA, K., Y. KOGA and M. KUDO. 1978. Differentiation from in vitro culture of Ananas comosus. Japan J.Breed. 28(2):113-121.

ZEPEDA, C. and Y. SAGAWA. 1981. In vitro propagation of pineapple. HortScience 16 (4):495.

\section{ABOUT THE AUTHOR}

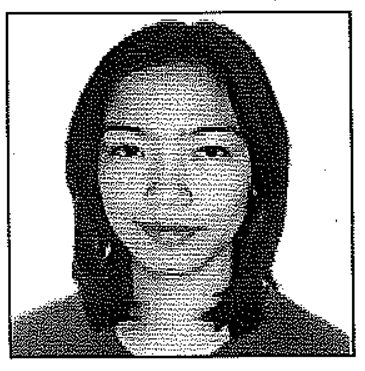

The author finished her Bachelor of Science in Agriculture in 1997, and her Master of Science major in Horticulture in 2002. She has been a Graduate Teaching Assistant of the Department of Horticulture, Leyte State University in 1997-2000. Presently, she is a Science Research Assistant at the Office of the Director for Research and Extension, LSU.

The co-author is a professor of the Department of Horticulture, Leyte State University, and is the major adviser of the senior author. 